\title{
Dermatological manifestations of the Coronavirus disease 2019 in children: a systemic review
}

\author{
Piotr Ciechanowicz' ${ }^{1}$ Klaudia Dopytalska ${ }^{1}$, Michał Szczerba², Elżbieta Szymańska ${ }^{1}$, Irena Walecka ${ }^{1}$ \\ ${ }^{1}$ Dermatology Department, Centre of Postgraduate Medical Education/Central Clinical Hospital MSWiA, Warsaw, Poland \\ ${ }^{2}$ Faculty of Medicine, University of Technology, Katowice, Poland
}

Adv Dermatol Allergol

DOI: https://doi.org/10.5114/ada.2020.99294

\begin{abstract}
Introduction: An increasing number of publications describing dermatoses associated with Coronavirus disease 2019 (COVID-19) have shown differences in the morphology and incidence of dermatoses in children compared to the general population.

Material and methods: Among 22 selected full-text articles, dermatoses associated with COVID-19 have been described in 196 children (average age: 12.57 years). Dermatoses were the only symptom in most patients $(n=134$; 68.4\%). RT-PCR tests of nasopharyngeal swabs confirmed SARS-CoV- 2 infection in only 18 cases $(n=18 / 69 ; 26.1 \%)$. Results: Dermatoses described include chilblain-like lesions ( $n=173 ; 88.3 \%)$, maculopapular rash $(n=16 ; 8.2 \%)$, erythema multiforme-like lesions ( $n=12 ; 6.1 \%)$, varicella-like exanthema $(n=1 ; 0.5 \%)$, and urticaria $(n=1 ; 0.5 \%)$. Conclusions: This publication aims to summarise existing data on dermatoses and to draw attention to how identification of dermatological symptoms in paediatric patients can provide a quick and reliable indicator of COVID-19.
\end{abstract}

Key words: COVID-19, coronavirus, SARS-CoV-2, paediatric, skin lesion, chilblain-like.

\section{Introduction}

The first cases of COVID-19 caused by SARS-CoV-2 appeared in Wuhan, China in December 2019 and the World Health Organisation (WHO) officially declared a pandemic on 11 March 2020 [1].

The most common symptoms include fatigue, fever, dry cough, muscle pain, and dyspnoea. Clinical symptoms also include gastrointestinal symptoms: nausea, vomiting, diarrhoea, as well as other symptoms such as rhinitis, sore throat, and loss of smell and taste. In severe cases the patients may develop acute respiratory distress syndrome (ARDS), arrhythmia and septic shock $[2,3]$. COVID-19 clotting disorders may lead to pulmonary embolism [4, 5] and ischaemic stroke [6].

However, studies worldwide have shown an increasing number of cases of skin lesions in patients with SARS-CoV-2 infections [7]. Galván Casas et al. [8] proposed a classification for skin lesions seen in the course of COVID-19 (based on 375 cases in paediatric and adult patients). The study identified maculopapular lesions (47\%), pseudo-chilblain-like lesions (19\%), urticaria lesions (19\%), follicular lesions (9\%) and reticular bruising/ necrotic lesions (e.g. livedo reticularis, necrosis, and acral ischaemia) (6\%) [8].

Although the basic symptoms of COVID-19 in children and adults are similar [9], the course of the disease in the paediatric population is more often mild or asymptomatic [10]. Thus, skin lesions may come to the forefront of the clinical picture of the disease.

However, there are some differences in the nature and incidence of individual dermatoses in adults and children.

\section{Aim}

This study aims to summarize data from publications on COVID-19-related skin lesions in the paediatric population.

\section{Material and methods \\ Searching strategy}

The systematic review was performed according to the Preferred Reporting Items for Systematic and Meta-Analysis (PRISMA) guidelines. The articles for this

\footnotetext{
Address for correspondence: Prof. Irena Walecka MD, PhD, Dermatology Department, Centre of Postgraduate Medical Education/ Central Clinical Hospital MSWiA, 137 Wołoska St, 02-507 Warsaw, Poland, phone: +48 $225081482,+48225081480$, e-mail: irena.walecka@cskmswia.pl Received: 17.07.2020, accepted: 20.08.2020.
} 
review were published or pre-print between 31 December 2019 and 1 June 2020 and can be found in PubMed and medRxiv. The following search phrases were used: "((COVID-19) OR (coronavirus) OR (Coronavirus disease) OR (SARS-CoV-2)) AND ((children) OR (paediatric)) AND ((skin) OR (Dermatology) OR (rash) OR (cutaneous))" as key words or MeSH terms. A number of 130 records were found through database searches. Duplicates and nonEnglish language articles were excluded.

Studies selected were required to be cross-sectional studies, cohort studies, case reports, and case series of paediatric patients meeting clinical criteria for diagnosis of COVID-19 and/or children with RT-PCR-confirmed SARS-CoV-2 infection. From 43 potentially appropriate articles that underwent evaluation, 22 full-text articles were found to be suitable for analysis (review articles, hypothesis articles, and publications with duplicated patients were excluded).

\section{Results}

\section{General overview (Table 1)}

Clinical cases of 196 patients with skin lesions in the course of COVID-19 were analysed. The average age of patients was 12.57 years; most of them were male.

Extracutaneous symptoms of COVID-19 occurred only in 62 described patients. The most common were: fever, gastrointestinal symptoms, and cough.

Analysing all available data on clinical cases with general symptoms, these were preceded by skin lesions by 8.9 days on average. Only in 3 patients, dermatoses appeared before other COVID-19 symptoms and in another 3 at the same time.

RT-PCR tests from nasopharyngeal swabs were performed in 69 patients, 18 of whom were positive.

In the analysed articles the most frequently observed symptom was chilblain-like lesions ( $n=173,88.3 \%$ ). Moreover, there were maculopapular rash $(n=16,8.2 \%)$ and erythema multiforme-like lesions ( $n=12,6.1 \%)$. One case each of a child with varicella-like exanthema (0.5\%) and urticaria (0.5\%) were described.

\section{Characteristics of skin lesions (Table 2) \\ Chilblain-like lesions}

Vascular dermatoses in the form of acute ischaemic lesions were initially described in adult patients with severe SARS-CoV-2 infection [11]. The above changes are likely to result from clotting disorders and are associated with microthrombi formation, leading to pulmonary embolism, strokes, and disseminated intravascular coagulation $[12,13]$.

However, recently, an increasing number of paediatricians, particularly those from regions most affected by COVID-19, have reported the occurrence of chilblain-like dermatoses among patients who have never previously experienced perniosis or Raynaud symptoms [14-16].

These changes initially manifest as erythematousbluish spots usually limited to the distal parts of the limbs, often with blisters, erosions and dry scab-covered ulcers. Upon healing, these lesions become spotted lesions $[14,17,18]$.

Pseudo-chilblain skin lesions occurred in 173 patients. The average age in this group of patients was 13.2 years and most of them were female. Dermatoses were most often located only on feet (143 patients). In 13 patients, lesions concerned only hands, in 13 cases both hands and feet. The average duration of skin lesions was 18.5 days; in $54.9 \%$ they were accompanied by the following symptoms: pruritus, pain, burning and coldness (Table 2).

Authors of many publications show that patients with pseudo-chilblain-like lesions present mild or no symptoms of viral disease, and RT-PCR tests from the nasopharyngeal swabs are often negative. This is probably due to the delayed occurrence of skin lesions in the course of COVID-19 in children and young adults [15, 19-21].

In our analysis, extradermal symptoms appeared only in 44 out of 173 described patients and were preceded by chilblain-like lesions by 10.4 days on average. The most common symptoms were cough, gastrointestinal symptoms and fever.

Of the 49 RT-PCR tests performed from nasopharyngeal swabs, only 10 were positive for SARS-CoV-2 (Table 2). Kolivras et al. [22] presented a histopathological picture of chilblain skin lesions, in which they described the papillary oedema of the skin with perivascular lymphocytic infiltration together with diffuse necrotic keratinocytes in superficial layers of the epidermis. Microangiopathic changes may be caused by an increased reaction associated with increased type 1 interferon production, which occurs during SARS-COV-2 infection, especially in children and young adults. However, it may be a protective factor against the occurrence of a 'cytokine storm' and full COVID-19 [19, 22, 23].

\section{Erythema multiforme-like lesions}

Erythema multiforme-like dermatosis $(n=12 / 196)$ is another type of a skin lesion described in the publications we analysed. The mean age was 12.1 years, the lesions were more common in boys.

Erythema multiforme-like dermatoses were most often located on feet. Less commonly, they were found on hands face, conjunctiva, lips, and in the oral cavity. The average duration of skin lesions was 16.7 days; $58.3 \%$ of them were accompanied by pruritus and pain. General symptoms associated with COVID-19 appeared in 5 out of 12 described patients and were preceded by erythema multiforme-like lesions by 21 days on average. The 


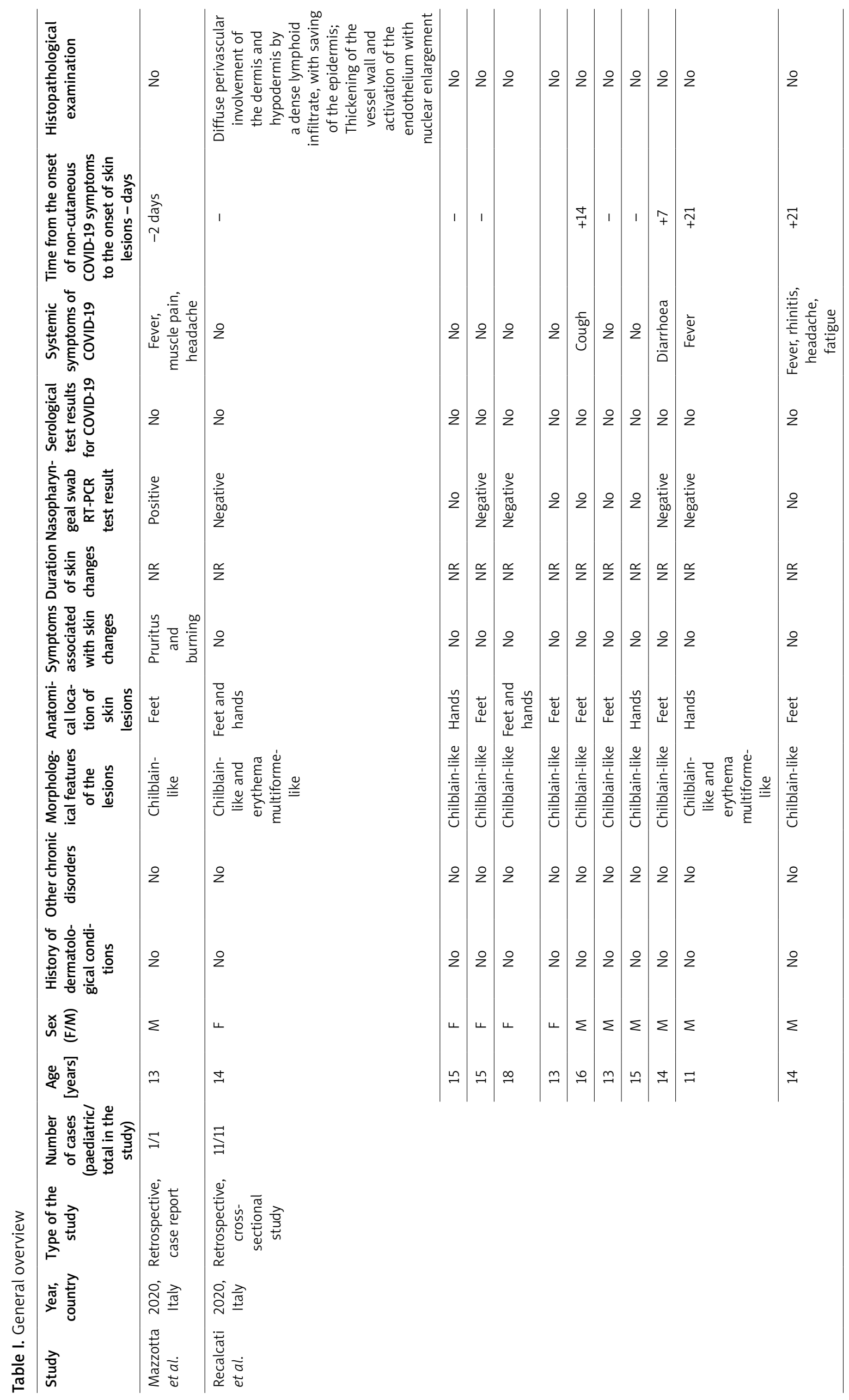




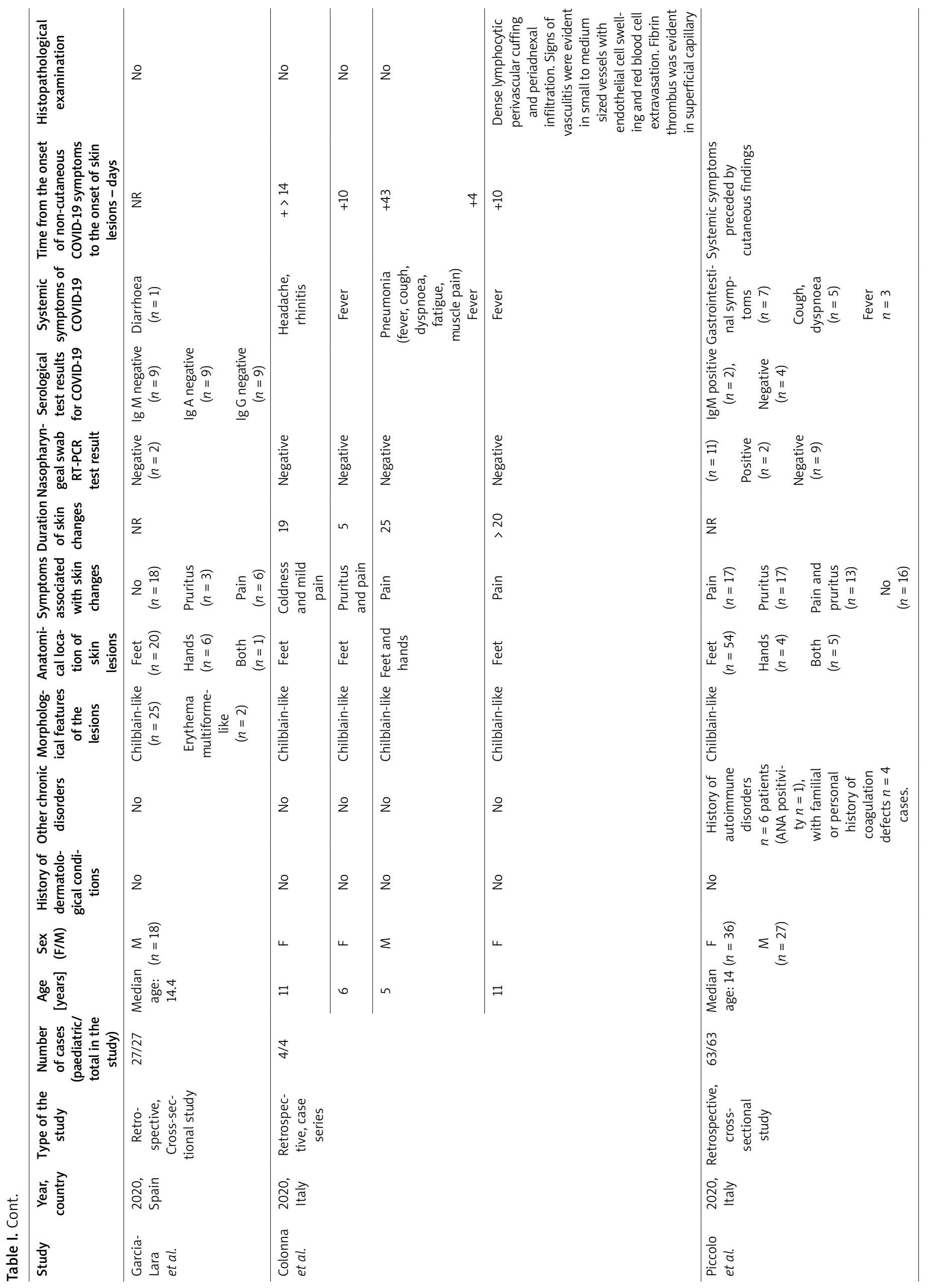




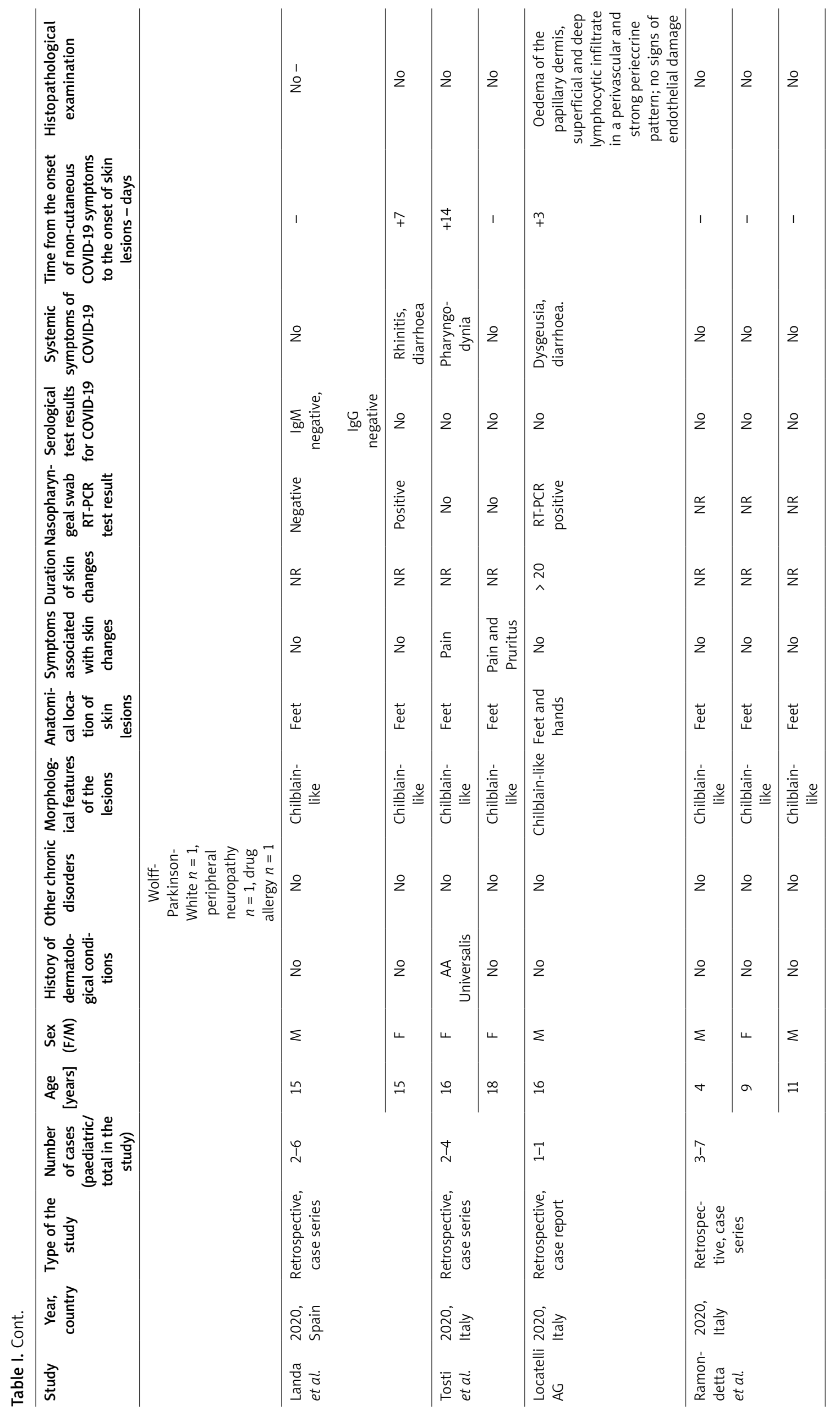




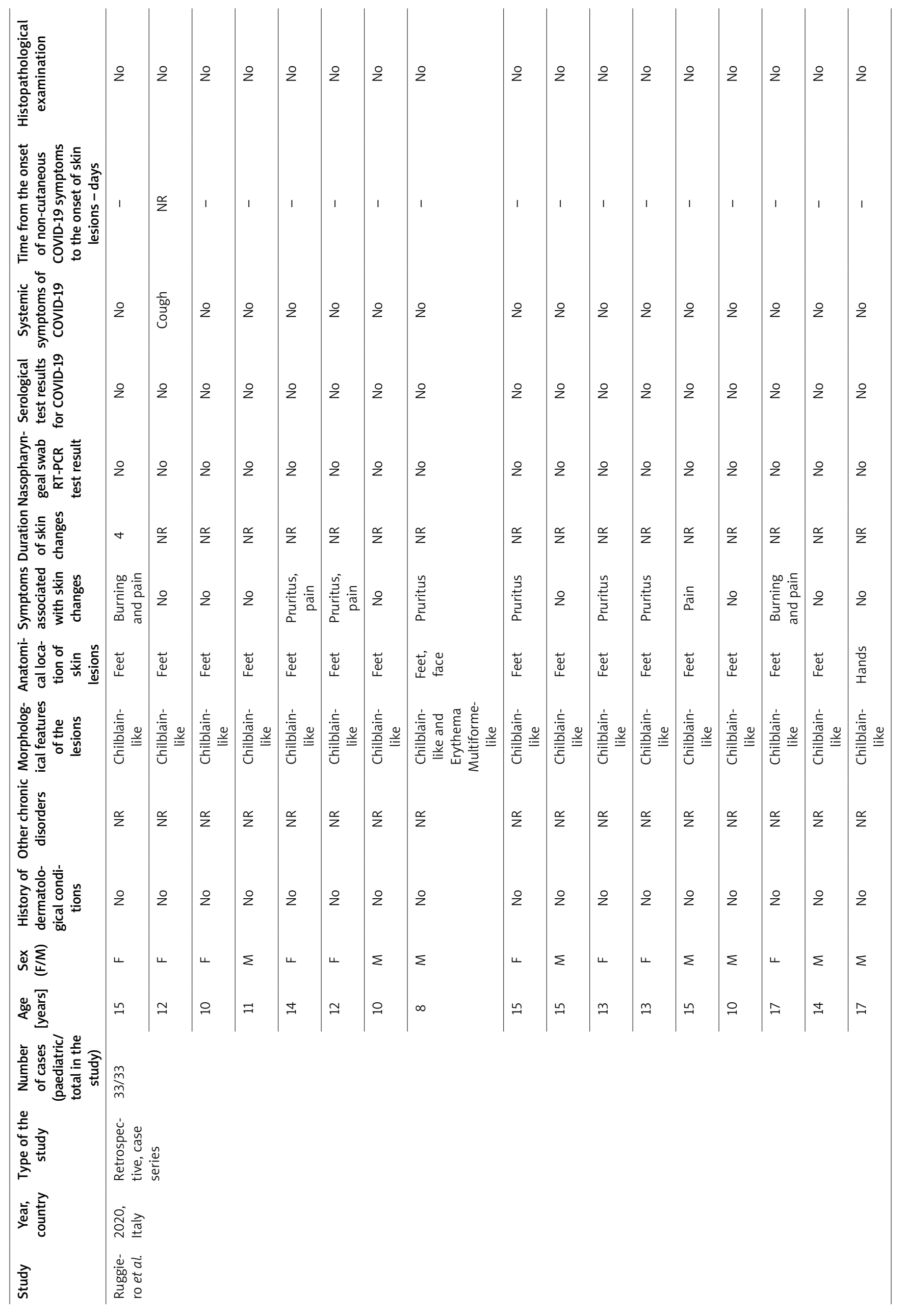




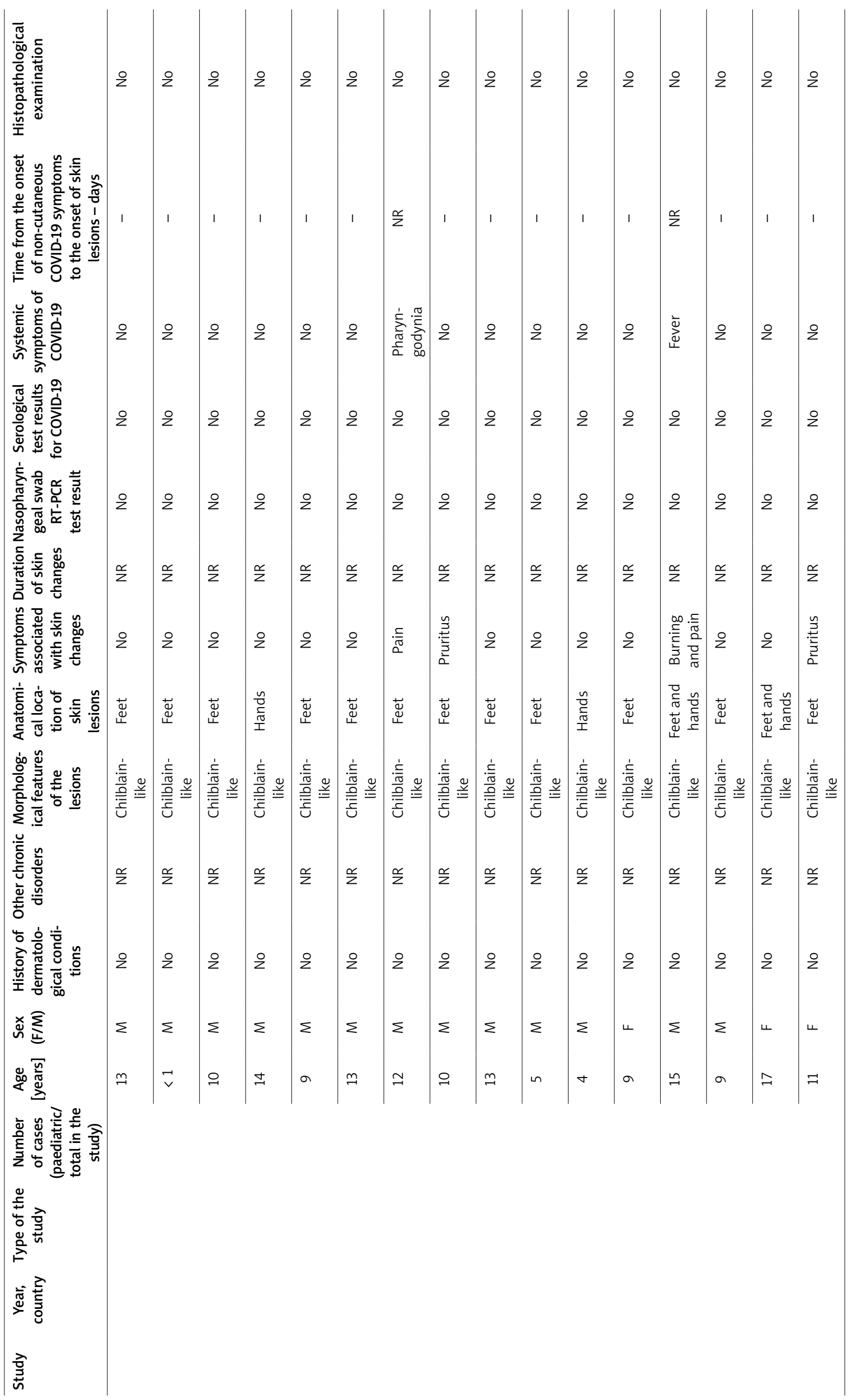




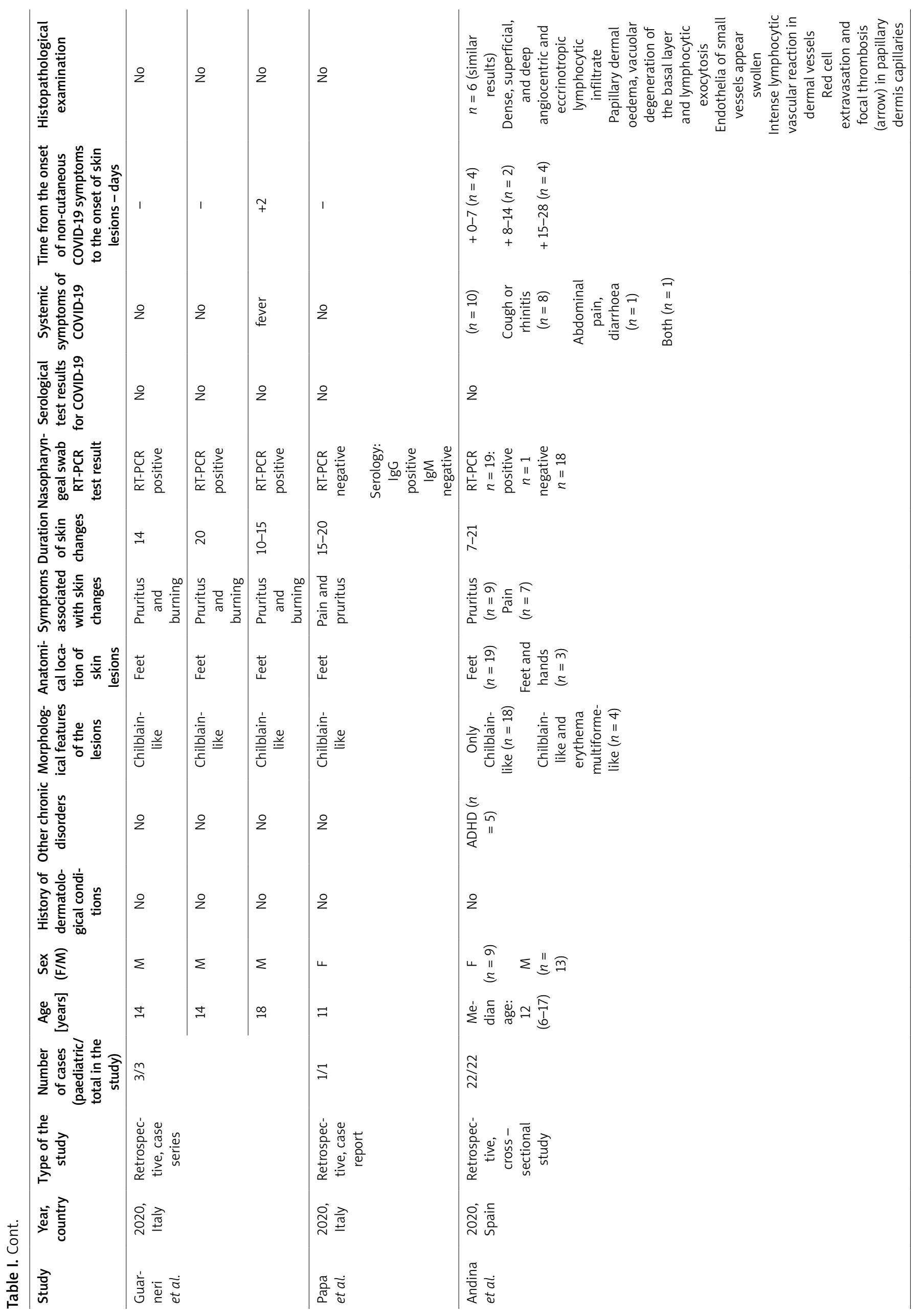




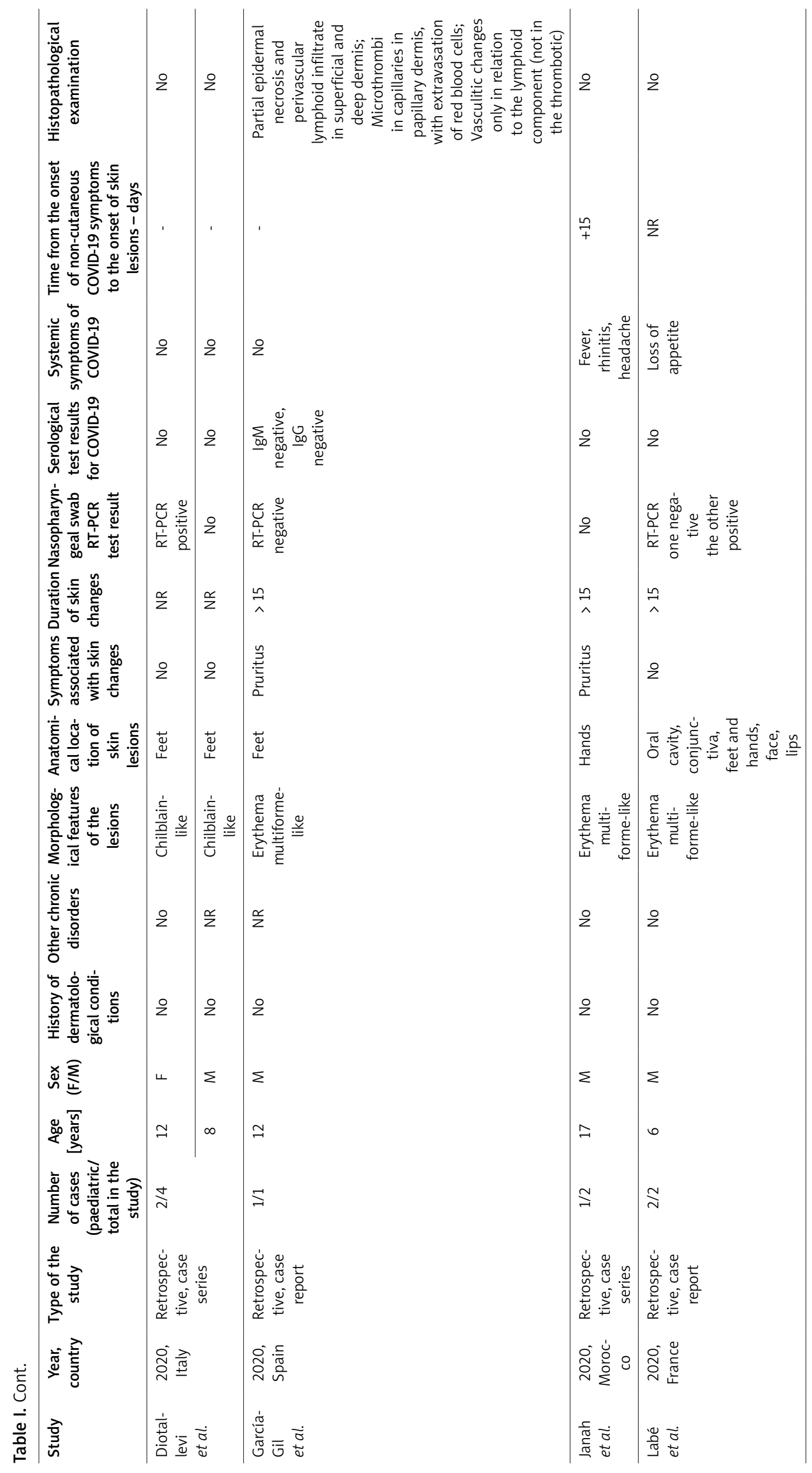




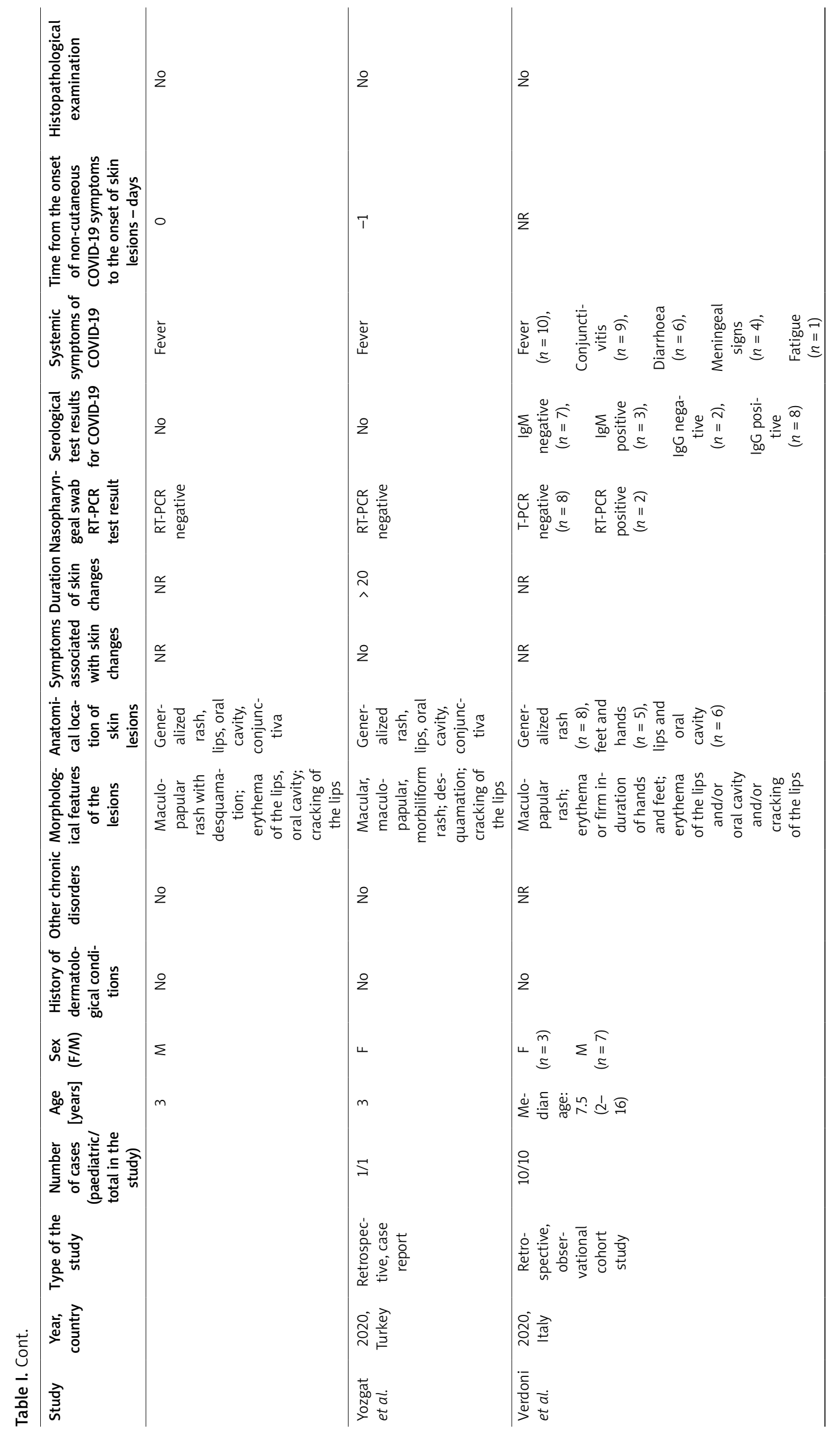




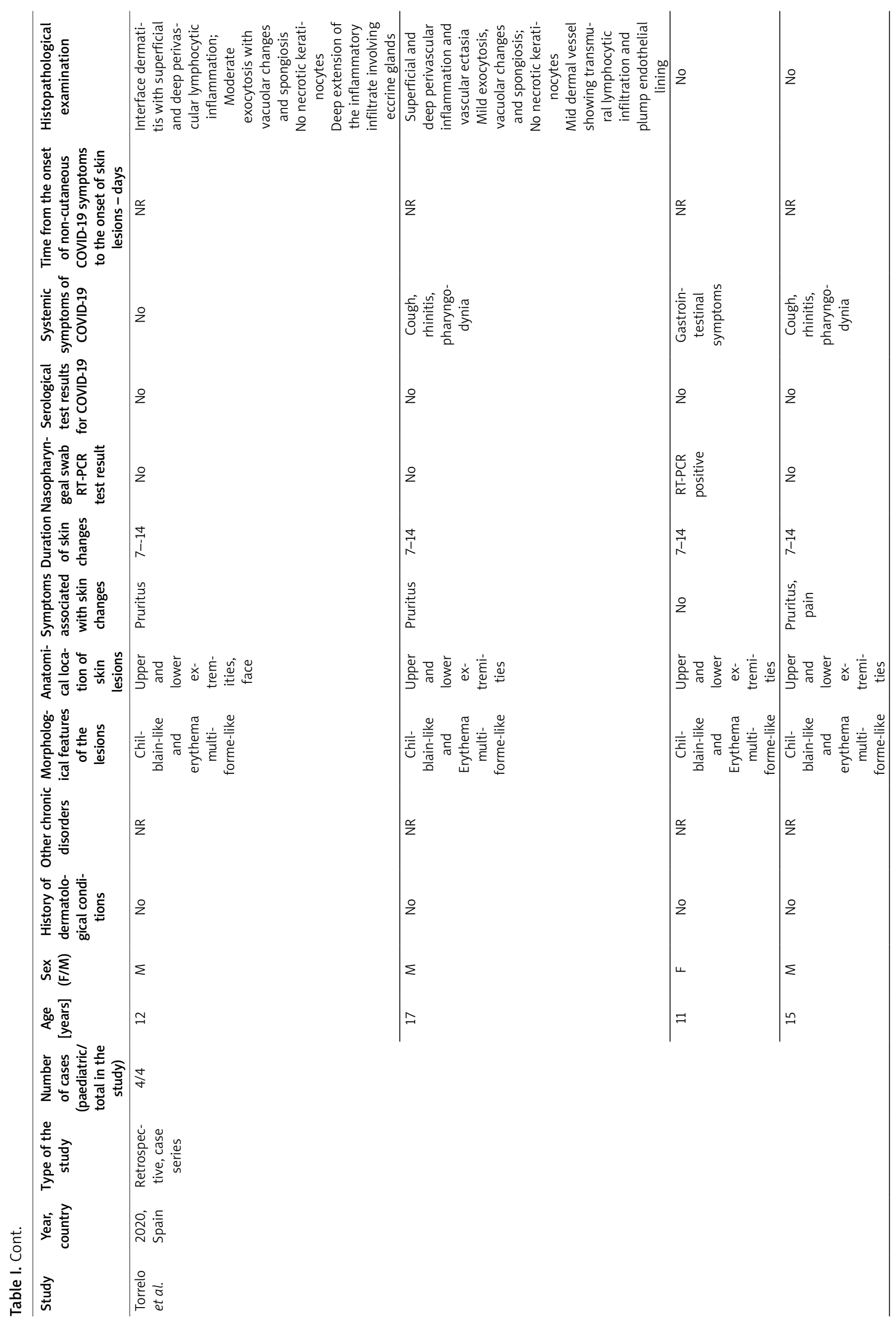




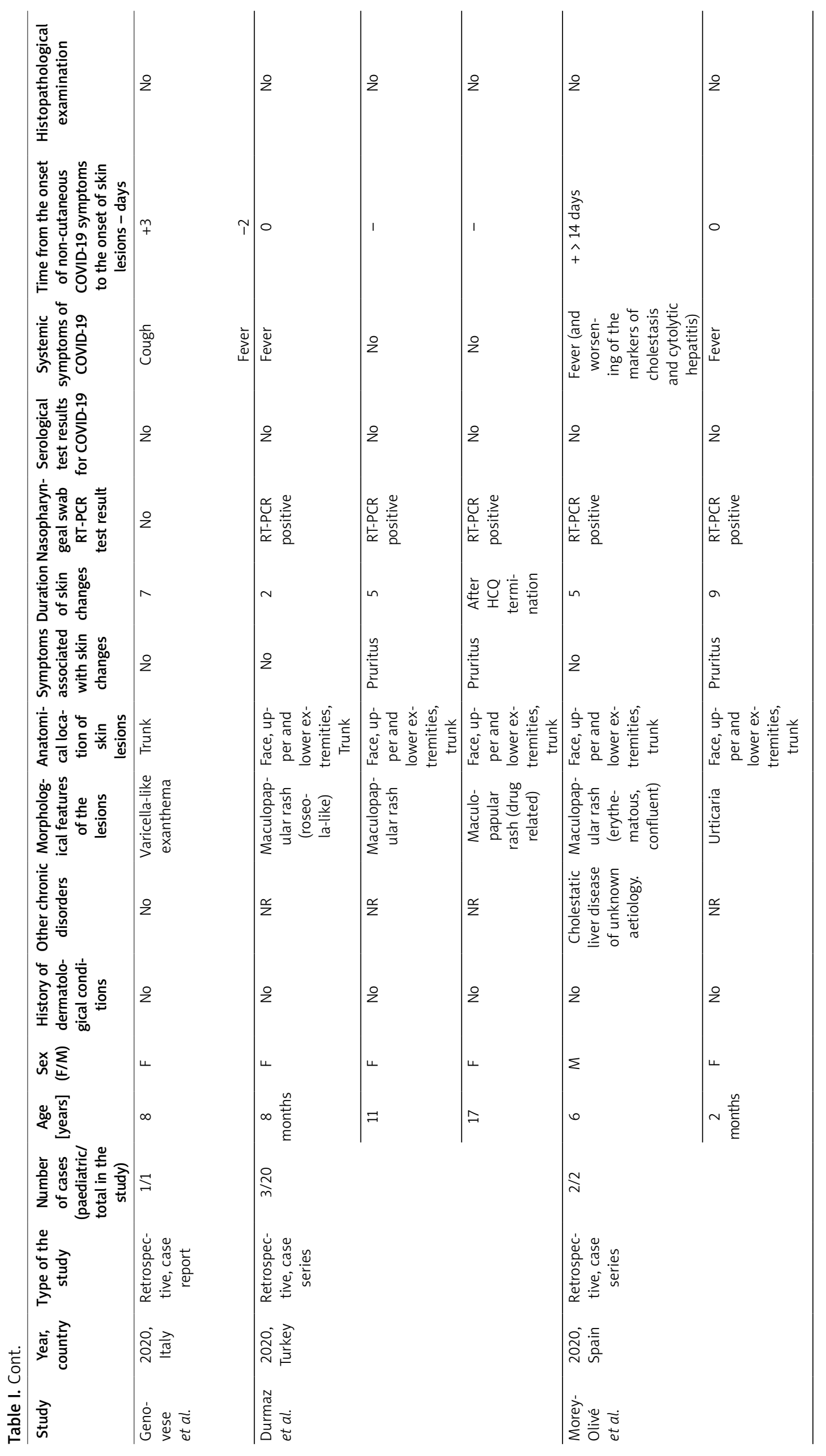


Table 2. Summary of the clinical characteristics

\begin{tabular}{|c|c|c|}
\hline \multicolumn{2}{|l|}{ Parameter } & General data \\
\hline \multicolumn{2}{|c|}{ Total number of cases } & 196 \\
\hline \multicolumn{2}{|c|}{ Mean age [years] (range) } & 12.57 \\
\hline \multirow[t]{2}{*}{ Sex } & Male, $n(\%)$ & 107 (54.6) \\
\hline & Female, $n(\%)$ & $89(45.4)$ \\
\hline \multirow{5}{*}{$\begin{array}{l}\text { Morphological } \\
\text { features of the } \\
\text { lesions }-n \\
\text { (\% of all cases) }\end{array}$} & Chilblain-like & $173(88.3)$ \\
\hline & $\begin{array}{c}\text { Maculopapular } \\
\text { rash }\end{array}$ & $16(8.2)$ \\
\hline & $\begin{array}{c}\text { Erythema } \\
\text { multiforme-like }\end{array}$ & $12(6.1)$ \\
\hline & $\begin{array}{l}\text { Varicella-like } \\
\text { exanthema }\end{array}$ & $1(0.5)$ \\
\hline & Urticaria & $1(0.5)$ \\
\hline \multirow{9}{*}{$\begin{array}{l}\text { Anatomical } \\
\text { location of skin } \\
\text { lesions }-n \\
\text { (\% of all cases) }\end{array}$} & Feet & 177 (91.7) \\
\hline & Hands & $45(23.3)$ \\
\hline & Trunk & $16(8.3)$ \\
\hline & Arms, forearms & $15(7.8)$ \\
\hline & Thighs, shins & $15(7.8)$ \\
\hline & Face & $10(5.2)$ \\
\hline & Lips & $9(4.7)$ \\
\hline & Oral cavity & $9(4.7)$ \\
\hline & Conjunctiva & $3(1.6)$ \\
\hline \multicolumn{2}{|c|}{ Mean duration of skin lesions [days] } & $17.2(2-25)$ \\
\hline \multirow{5}{*}{$\begin{array}{l}\text { Symptoms } \\
\text { associated with } \\
\text { skin lesions }-n \\
\text { (\% of all cases) }\end{array}$} & Pruritus & $62(31.6)$ \\
\hline & Pain & $57(29.1)$ \\
\hline & Burning & $7(3.6)$ \\
\hline & Coldness & $1(0.5)$ \\
\hline & No & $95(48.5)$ \\
\hline \multirow{2}{*}{$\begin{array}{l}\text { Nasopharyngeal } \\
\text { swab RT-PCR test } \\
\text { result }(n=69) \text {, } \\
n(\%)\end{array}$} & Positive & $18(26.1)$ \\
\hline & Negative & $51(73.9)$ \\
\hline \multirow{12}{*}{$\begin{array}{l}\text { Systemic } \\
\text { symptoms of } \\
\text { COVID-19 - } n \\
\text { (\% of all cases) }\end{array}$} & Fever & $28(14.4)$ \\
\hline & $\begin{array}{l}\text { Gastrointestinal } \\
\text { symptoms }\end{array}$ & $20(10.3)$ \\
\hline & Cough & $18(9.3)$ \\
\hline & Conjunctivitis & $9(4.6)$ \\
\hline & Rhinitis & $8(4.1)$ \\
\hline & Dyspnoea & $6(3.1)$ \\
\hline & Headache & $4(2.1)$ \\
\hline & Meningeal signs & $4(2.1)$ \\
\hline & Fatigue & $3(1.5)$ \\
\hline & Pharyngodynia & $2(1.0)$ \\
\hline & Muscle pain & $2(1.0)$ \\
\hline & No & $134(68.4)$ \\
\hline
\end{tabular}

\begin{tabular}{|c|c|c|}
\hline \multicolumn{2}{|l|}{ Parameter } & General data \\
\hline \multicolumn{2}{|c|}{$\begin{array}{l}\text { Mean time from the onset of non- } \\
\text { cutaneous COVID-19 symptoms to the } \\
\text { onset of skin lesions [days] }\end{array}$} & $8.9(-2-28)$ \\
\hline \multicolumn{3}{|c|}{ Chilblain-like lesions $(n=173)$} \\
\hline \multicolumn{2}{|c|}{ Total number of cases } & 173 \\
\hline \multicolumn{2}{|c|}{ Mean age (range) [years] } & $\begin{array}{l}13.2 \text { ( } 8 \text { months } \\
-18 \text { years) }\end{array}$ \\
\hline \multirow[t]{2}{*}{ Sex } & Male, $n(\%)$ & $79(45.7)$ \\
\hline & Female, $n(\%)$ & $94(54.3)$ \\
\hline \multirow{4}{*}{$\begin{array}{l}\text { Anatomical } \\
\text { location of skin } \\
\text { lesions }-n \\
\text { (\% of all cases) }\end{array}$} & Only feet & $143(82.7)$ \\
\hline & Only hands & $13(7.5)$ \\
\hline & $\begin{array}{l}\text { Both feet and } \\
\text { hands }\end{array}$ & $13(7.5)$ \\
\hline & Face & $2(20)$ \\
\hline \multicolumn{2}{|c|}{$\begin{array}{l}\text { Mean duration of skin lesions (range) } \\
\text { [days] }\end{array}$} & $18.5(4-25)$ \\
\hline \multirow{5}{*}{$\begin{array}{l}\text { Symptoms } \\
\text { associated with } \\
\text { skin lesions }-n \\
\text { (\% of all cases) }\end{array}$} & Pruritus & $57(32.9)$ \\
\hline & Pain & $56(32.4)$ \\
\hline & Burning & $7(4.0)$ \\
\hline & Coldness & $1(0.6)$ \\
\hline & No & $78(45.1)$ \\
\hline \multirow{2}{*}{$\begin{array}{l}\text { Nasopharyngeal } \\
\text { swab RT-PCR test } \\
\text { result }(n=49) \text {, } \\
n(\%)\end{array}$} & Positive & $10(20.4)$ \\
\hline & Negative & $39(79.6)$ \\
\hline \multirow{10}{*}{$\begin{array}{l}\text { Systemic } \\
\text { symptoms of } \\
\text { COVID-19 }-n \\
\text { (\% of all cases) }\end{array}$} & Cough & $17(9.8)$ \\
\hline & $\begin{array}{l}\text { Gastrointestinal } \\
\text { symptoms }\end{array}$ & $13(7.5)$ \\
\hline & Fever & $11(6.4)$ \\
\hline & Rhinitis & $7(4.0)$ \\
\hline & Dyspnoea & $6(3.5)$ \\
\hline & Headache & $3(1.7)$ \\
\hline & Fatigue & $3(1.5)$ \\
\hline & Pharyngodynia & $2(1.2)$ \\
\hline & Muscle pain & $2(1.2)$ \\
\hline & No & $129(74.6)$ \\
\hline \multicolumn{2}{|c|}{$\begin{array}{l}\text { Mean time from the onset of non- } \\
\text { cutaneous COVID-19 symptoms to the } \\
\text { onset of skin lesions (range) [days] }\end{array}$} & $10.4(-2-28)$ \\
\hline
\end{tabular}


Table 2. Cont.

\begin{tabular}{|c|c|c|}
\hline \multicolumn{2}{|l|}{ Parameter } & General data \\
\hline \multicolumn{3}{|c|}{ Maculopapular rash $(n=16)$} \\
\hline \multicolumn{2}{|c|}{ Total number of cases } & 16 \\
\hline \multicolumn{2}{|c|}{ Mean age (range) [years] } & $\begin{array}{l}7.22 \text { ( } 8 \text { months - } \\
17 \text { years) }\end{array}$ \\
\hline \multirow[t]{2}{*}{ Sex } & Male, $n(\%)$ & $9(56.3)$ \\
\hline & Female, $n(\%)$ & $7(43.7)$ \\
\hline \multirow{9}{*}{$\begin{array}{l}\text { Anatomical } \\
\text { location of skin } \\
\text { lesions }-n \\
\text { (\% of all cases) }\end{array}$} & Feet & $16(100)$ \\
\hline & Hands & $16(100)$ \\
\hline & Arms, forearms & $14(87.5)$ \\
\hline & Thighs, shins & $14(87.5)$ \\
\hline & Trunk & $14(87.5)$ \\
\hline & Lips & $8(50)$ \\
\hline & Oral cavity & $8(50)$ \\
\hline & Face & $6(37.5)$ \\
\hline & Conjunctiva & $2(12.5)$ \\
\hline \multicolumn{2}{|c|}{$\begin{array}{l}\text { Mean duration of skin lesions (range) } \\
\text { [days] }\end{array}$} & $9.3(2-25)$ \\
\hline \multirow{3}{*}{$\begin{array}{l}\text { Symptoms } \\
\text { associated with } \\
\text { skin lesions - } \\
\text { (\% of all cases) }\end{array}$} & Pruritus & $2(12.5)$ \\
\hline & Burning & $7(4.0)$ \\
\hline & No & $14(87.5)$ \\
\hline \multirow{2}{*}{$\begin{array}{l}\text { Nasopharyngeal } \\
\text { swab RT-PCR test } \\
\text { result }(n=16) \\
-n(\%)\end{array}$} & Positive & $6(37.5)$ \\
\hline & Negative & $10(62.5)$ \\
\hline \multirow{6}{*}{$\begin{array}{l}\text { Systemic } \\
\text { symptoms of } \\
\text { COVID-19 }-n \\
\text { (\% of all cases) }\end{array}$} & Fever & $14(87.5)$ \\
\hline & Conjunctivitis & $9(56.3)$ \\
\hline & $\begin{array}{l}\text { Gastrointestinal } \\
\text { symptoms }\end{array}$ & $6(37.5)$ \\
\hline & Meningeal signs & $4(25)$ \\
\hline & Fatigue & $1(6.3)$ \\
\hline & No & $2(12.5)$ \\
\hline \multicolumn{2}{|c|}{$\begin{array}{l}\text { Mean time from the onset of non- } \\
\text { cutaneous COVID-19 symptoms to the } \\
\text { onset of skin lesions (range) [days] }\end{array}$} & $3.5(-1-15)$ \\
\hline
\end{tabular}

most common symptoms were fever and gastrointestinal symptoms. RT-PCR tests from nasopharyngeal swabs were performed in majority of the patients from this group $(n=8)$, positive results for SARS-CoV-2 were found only in two children (Table 2).

Torrelo et al. and Andina et al. [19, 24] presented an interesting description of 4 children aged 11-17 years who had erythema multiforme-like lesions in addition to chilblain-like lesions on the feet (in 4 patients) and hands (in 2 patients). The subjects had never before experienced such symptoms, had not taken new medications, and had not received vaccinations during the previous

\begin{tabular}{|c|c|c|}
\hline \multicolumn{2}{|l|}{ Parameter } & General data \\
\hline \multicolumn{3}{|c|}{ Erythema multiforme-like lesions $(n=12)$} \\
\hline \multicolumn{2}{|c|}{ Total number of cases } & 12 \\
\hline \multicolumn{2}{|c|}{ Mean age (range) [years] } & $12.1(6-17)$ \\
\hline \multirow[t]{2}{*}{ Sex } & $\begin{array}{l}\text { Male }-n(\% \text { of all } \\
\text { cases })\end{array}$ & $9(75)$ \\
\hline & $\begin{array}{l}\text { Female }-n(\% \text { of } \\
\text { all cases })\end{array}$ & $3(25)$ \\
\hline \multirow{7}{*}{$\begin{array}{l}\text { Anatomical } \\
\text { location of skin } \\
\text { lesions }-n \\
\text { (\% of all cases) }\end{array}$} & Only feet & $7(58.3)$ \\
\hline & Only hands & $2(16.7)$ \\
\hline & $\begin{array}{l}\text { Both feet and } \\
\text { hands }\end{array}$ & $3(25)$ \\
\hline & Face & $2(16.7)$ \\
\hline & Lips & $1(8.3)$ \\
\hline & Oral cavity & $1(8.3)$ \\
\hline & Conjunctiva & $1(8.3)$ \\
\hline \multicolumn{2}{|c|}{$\begin{array}{l}\text { Mean duration of skin lesions (range) } \\
\text { [days] }\end{array}$} & $16.7(14-21)$ \\
\hline \multirow{3}{*}{$\begin{array}{l}\text { Symptoms } \\
\text { associated with } \\
\text { skin lesions - } \\
n \text { (\% of all cases) }\end{array}$} & Pruritus & $5(41.7)$ \\
\hline & Pain & $2(16.7)$ \\
\hline & No & $5(41.7)$ \\
\hline \multirow{2}{*}{$\begin{array}{l}\text { Nasopharyngeal } \\
\text { swab RT-PCR test } \\
\text { result }(n=8)- \\
n(\%)\end{array}$} & Positive & $2(25)$ \\
\hline & Negative & $6(75)$ \\
\hline \multirow{7}{*}{$\begin{array}{l}\text { Systemic } \\
\text { symptoms of } \\
\text { COVID-19 }-n \\
\text { (\% of all cases) }\end{array}$} & Cough & $1(8.3)$ \\
\hline & $\begin{array}{l}\text { Gastrointestinal } \\
\text { symptoms }\end{array}$ & $2(16.7)$ \\
\hline & Fever & $2(16.7)$ \\
\hline & Cough & $1(8.3)$ \\
\hline & Rhinitis & $1(8.3)$ \\
\hline & Headache & $1(8.3)$ \\
\hline & No & $7(58.3)$ \\
\hline \multicolumn{2}{|c|}{$\begin{array}{l}\text { Mean time from the onset of non- } \\
\text { cutaneous COVID-19 symptoms to the } \\
\text { onset of skin lesions [days] }\end{array}$} & $21.0(15-28)$ \\
\hline
\end{tabular}

30 days, and did not have any symptoms of or exposure to herpes virus, Epstein-Barr virus, varicella, adenovirus, cytomegalovirus, or orf. RT-PCR testing for SARS-CoV-2 was positive in only 1 of the patients; another had contact with a family member with suspected infection; 3 had mild symptoms of COVID-19 a few days before the appearance of skin lesions. Histopathological examination performed in 2 patients did not show an erythema multiforme characteristic picture, but immunohistochemistry was positive for SARS-CoV/SARS-CoV-2 spike protein. Oral corticosteroids have been administered in 1 patient and topical corticosteroids were used in anoth- 
er. Skin lesions disappeared without complications in all patients within one to 3 weeks $[19,24]$.

García-Gil et al. [25] in their publication presented a clinical case of a 12-year-old boy with erythema multiforme-like skin changes which presented as purple erythematous lesions and vesicular blisters.

Histopathological examination of skin lesions revealed partial epidermal necrosis and perivascular lymphoid infiltrate in superficial and deep dermis, microthrombi of the papillary dermis accompanied by extravasation of red blood cells, thickening of the vessel wall, and activation of the endothelium with nuclear enlargement. The authors of the publication emphasized the similarity of the histopathological image of erythema multiforme-like lesions (pauci-inflammatory thrombogenic vasculopathy) to vascular lesions occurring in adult patients with severe COVID-19. This suggests that SARSCoV-2 may be an etiological factor in the development of acute vascular lesions in children despite often negative test results confirming the infection.

\section{Maculopapular changes}

The clinical picture of patients with maculopapular lesions was quite diverse. In the analysed articles, 16 cases of children with maculopapular exanthema (8.2\%) were described. The average age of patients in the analysed articles was 7.22 years, the changes were more frequent in boys. In all described clinical cases, the changes concerned hands and feet. Moreover, in 14 patients a generalized rash on whole upper and lower extremities and trunk was found.

The average duration of the exanthema was 9.3 days. Only itching was described among the accompanying symptoms. The most frequently described general symptoms of COVID-19 were: fever, conjunctivitis and gastrointestinal symptoms. Extracutaneous symptoms in this group of patients appeared on average 3.5 days before the occurrence of maculopapular rash. RT-PCR tests of nasopharyngeal swabs were performed in all children in analysed clinical cases, most of the results were negative (Table 2).

Bursal Duramaz et al. [26] described two clinical cases of patients with confirmed SARS-CoV-2 infection who did not require systemic treatment. In an 8-month-old infant, an erythematous rash of the face and trunk resembling roseola was found. These skin changes and a fever appeared and subsided simultaneously. An 11-year-old girl presented with a pruritic, morbiliform rash on the face and back. The changes disappeared spontaneously after 5 days.

The course of COVID-19 among paediatric patients is often asymptomatic or has few symptoms [27, 28]; thus, systemic treatment is less frequently used compared to in the adult population.

However, Bursal Duramaz et al. [26] described a case report of a 17-year-old female patient experiencing a drug eruption on day 3 of hydroxychloroquine use. Erythematous and maculopapular changes occurred on the face and limbs with slight itching. Symptoms disappeared upon termination of hydroxychloroquine treatment.

Morey-Olivé et al. [29] described an interesting clinical case of a 6-year-old boy with cholestatic liver disease of unknown aetiology. Two weeks after a slight fever, elevated bilirubin and hepatic transaminases in blood, the patient had a positive result of RT-PCR smear test for the presence of SARS-CoV-2. After the next $48 \mathrm{~h}$ an itchy, non-smelling, generalised, dewy sediment appeared. Skin lesions persisted in the boy for a total of 5 days, were not accompanied by any symptoms associated with COVID-19 and upon their subsidence, liver parameters normalised. Interestingly, no SARS-CoV-2 was detected in the liver extract.

However, in 3 of the publications we analysed [3032], the erythematous and papular lesions occurred in the form of a generalised rash with subsequent epidermal exfoliation with often accompanying erythema or firm induration of hands and feet, erythema of the lips or oral cavity, and cracking of the lips.

In addition, the patients were found to have additional symptoms characteristic of Kawasaki's disease, namely fever, coronary artery abnormalities, hypotension and/or elevated inflammatory markers.

Labé et al. [31] presented a clinical case of a 3-yearold patient hospitalized for 8 days of high fever, whose mother was diagnosed with SARS-COV-2 infection 3 weeks earlier. The patient was described as generalized exanthema with desquamation of the extremities, bilateral palmar oedema, glossitis, and cervical lymphadenopathy. Laboratory tests showed an increase in inflammation parameters.

Although the result of the RT-PCR swab test for SARS-CoV-2 was negative, the ground-glass opacities and consolidation in the right posterobasal area clearly supported the diagnosis of COVID-19. According to the authors, the clinical case presented in the publication suggests that SARS-CoV-2 infection may be the trigger for Kawasaki-like disease [31].

In April 2020, there were reports from Europe and North America about a severe form of Paediatric Inflammatory Multisystem Syndrome (PIMS) sharing common features with other paediatric inflammatory conditions including: Kawasaki disease (KD), staphylococcal and streptococcal toxic shock syndromes, bacterial sepsis and macrophage activation syndromes. A possible temporal association of PIMS with SARS-COV-2 infection has been proposed as some paediatric patients have tested positively for SARS-CoV-2 infection using either polymerase chain reaction (PCR) or serological testing [30-34].

The initial definition of the Paediatric Inflammatory Multisystem Syndrome temporally associated with SARSCoV-2 infection $[35,36]$ based on a document published by the WHO on 15 May 2020 [37] covers children and 
adolescents under 19 years of age with a fever lasting 3 days or more, presenting at least two of the following symptoms:

- rash or non-purulent, bilateral conjunctivitis or symptoms of mucocutaneous inflammation signs (oral, hands, or feet),

- hypotension or shock,

- features of myocardial dysfunction, pericarditis, valvular inflammation, or coronary artery abnormalities,

- coagulopathy,

- acute gastrointestinal symptoms.

Additionally, diagnosis requires elevated inflammatory markers, exclusion of other infectious causes of presented symptoms, and either confirmation of COVID-19 or probable contact with an infected individual [37].

PIMS-TS symptoms are similar to those of KD, including persistent fever and coronary artery damage; however, relatively older children are typically affected [38, 39].

Verdoni et al. pointed out a significant increase in the incidence of KD symptoms in the Italian Bergamo area since the beginning of the SARS-COV-2-related pandemic, particularly a 30-fold increase in the incidence of Kawasaki-like disease between 18.02.2020 and 20.04.2020. Compared to patients admitted before February 2020, only in the group of children hospitalized after the beginning of coronavirus epidemic, KD shock syndrome and features of macrophage activation syndrome were reported [30].

While the aetiology of KD is still not fully understood, available studies suggest that the disease may be due to abnormal regulation of the immune system in response to the infectious agent. This inappropriate immune response is most probably genetic as indicated by the limited number of cases of children with KD in the course of infectious diseases. A hypothesis to explain the aetiology of PIMS-TS has yet been put forward [40, 41].

Patients with PIMS-TS symptoms require immediate hospitalization. Treatment of this disease is similar to that of KD. First-line treatment is high-dose intravenous immunoglobulin (IVIG) $(2 \mathrm{~g} / \mathrm{kg})$ to reduce the risk of coronary artery damage. Additionally, acetylsalicylic acid, corticosteroids, and anti-TNF monoclonal antibodies may be used to reduce inflammation [42].

\section{Other skin lesions}

Among the analysed publications, single clinical cases of children with papulovesicular skin changes and urticaria were presented.

\section{Varicella-like exanthema}

Genovese et al. [43] presented a description of an 8-year-old girl, hospitalized due to varicella-like exanthema lasting for 3 days and a positive RT-PCR result from nasopharyngeal swabs for SARS-CoV-2 (in the patient and her closest family). In the history, the patient had smallpox a year earlier.

On admission, disseminated papular, papular-bladder lesions with a tendency to crack and scab formation in the area of the torso skin were found. The skin lesions were accompanied by only a slight cough, which occurred 3 days before the onset of the skin lesions, and a fever, which occurred on the $2^{\text {nd }}$ day of dermatosis. Laboratory tests were all within normal range except for slight thrombocytopenia. Skin lesions and general ailments disappeared without any treatment within 7 days.

\section{Urticaria}

Urticaria is a rare disease in childhood (3.4\% UK, 4.4\% Germany, 5.4\% Denmark) and the risk of transformation into a chronic form is negligible (0.1-0.3\%) [44-46]. Scientific studies show that viral infections can also be an etiological factor in urticaria [47, 48].

Morey-Olivé et al. [29] described a clinical case of a 2-month-old girl with itchy acute urticaria skin lesions lasting 4 days and accompanied by a slight fever. The girl had contact with two people with confirmed SARS-CoV-2 infection. The urticaria initially occurred on the face and upper limbs and subsequently spread to the trunk and lower limbs. The palms and soles remained free of lesions and no angioedema was found. After oral symptomatic treatment, all symptoms disappeared within 5 days.

\section{Conclusions}

An increasing number of publications regarding skin lesions in the course of COVID-19 are describing skin lesions occurring in children. The preceding examples show that both the morphology and prevalence of particular dermatoses in the course of COVID-19 is different in children compared to these found in adults.

In many cases, skin lesions are the only visible manifestation of the disease in the paediatric population, and RT-PCR tests from nasopharyngeal swabs and serological tests confirming SARS-CoV-2 infection may be negative.

However, the histopathological picture of acute chilblain-like lesions and erythema multiforme-like lesions in children shows similarity to vascular lesions in adult patients with severe COVID-19.

While symptoms in the paediatric population are typically mild, there is an increasing number of reports of severe COVID-19 in the form of multi-systemic inflammatory disease resembling an incomplete picture of Kawasaki disease, most probably related to SARS-CoV-2 infection.

Case reports of clinical skin lesions in the course of COVID-19 in children indicates that there is a need for large, comprehensive studies confirming the characteristics and prevalence of dermatoses associated with SARS-CoV-2 infection. Precise and rapid diagnosis, includ- 
ing skin lesions, may prove to be crucial for rapid medical intervention to prevent further spread of the disease, especially in the paediatric population, where skin lesions may be the only manifestation of COVID-19.

\section{Conflict of interest}

The authors declare no conflict of interest.

\section{References}

1. World Health Organization. Novel Coronavirus Situation Reports 2020. Available from: https://covid19.who.int.

2. Wang D, Hu B, Hu C, et al. Clinical characteristics of 138 hospitalized patients with 2019 novel coronavirus-infected pneumonia in Wuhan, China. JAMA 2020; 323: 1061-9.

3. Huang C, Wang Y, Li X, et al. Clinical features of patients infected with 2019 novel coronavirus in Wuhan, China. Lancet 2020; 395: 497-506.

4. Zuckier LS, Moadel RM, Haramati LB, et al. Diagnostic evaluation of pulmonary embolism during the COVID-19 pandemic. J Nucl Med 2020; 61: 630-1.

5. Cao M, Zhang D, Wang Y, et al. Clinical features of patients infected with the 2019 novel Coronavirus (COVID-19) in Shanghai, China. medRxiv 2020 https://doi.org/10.1101/20 20.03.04.20030395.

6. Carod-Artal FJ. Neurological complications of coronavirus and COVID-19. Rev Neurol 2020; 70: 311-22.

7. Ciechanowicz P, Szymanska E, Wiszniewski K, et al. Cutaneous manifestations of coronavirus disease 2019 - review of literature and case reports. Adv Dermatol Allergol 2020 https://doi.org/10.5114/ada.2020.95958.

8. Galvan Casas C, Catala A, Carretero Hernandez G, et al. Classification of the cutaneous manifestations of COVID-19: a rapid prospective nationwide consensus study in Spain with 375 cases. Br I Dermatol 2020; 183: 71-7.

9. Team CC-R. Coronavirus Disease 2019 in Children - United States, February 12-April 2, 2020. MMWR Morb Mortal Wkly Rep 2020; 69: 422-6.

10. Sankar J, Dhochak N, Kabra SK, et al. COVID-19 in children: clinical approach and management. Indian J Pediatr 2020; 87: 433-42.

11. Zhang Y, Cao W, Xiao M, et al. Clinical and coagulation characteristics of 7 patients with critical COVID-2019 pneumonia and acro-ischemia. Zhonghua Xue Ye Xue Za Zhi 2020; 41: E006.

12. Tang N, Li D, Wang X, et al. Abnormal coagulation parameters are associated with poor prognosis in patients with novel coronavirus pneumonia. J Thromb Haemost 2020; 18: 844-7.

13. Danzi GB, Loffi M, Galeazzi G, et al. Acute pulmonary embolism and COVID-19 pneumonia: a random association? Eur Heart J 2020; 41: 1858.

14. Colonna C, Monzani NA, Rocchi A, et al. Chilblain-like lesions in children following suspected COVID-19 infection. Pediatr Dermatol 2020; 37: 437-40.

15. Garcia-Lara G, Linares-Gonzalez L, Rodenas-Herranz T, et al. Chilblain-like lesions in pediatrics dermatological outpatients during the COVID-19 outbreak. Dermatol Ther 2020: e13516. doi: 10.1111/dth.13516.

16. Ramondetta A, Panzone M, Dapavo P, et al. Chilblain acral lesions in the COVID-19 era. Are they marker of infection in asymptomatic patients? J Eur Acad Dermatol Venereol 2020 https://doi.org/10.1111/jdv.16636.

17. Mazzotta F, Troccoli T. Acute acro-ischemia in the child at the time of COVID-19. Eur J Pediatr Dermatol 2020; 30: 71-4.

18. Locatelli AG, Robustelli Test E, Vezzoli P, et al. Histologic features of long-lasting chilblain-like lesions in a paediatric COVID-19 patient. J Eur Acad Dermatol Venereol 2020; 34 : e365-8.

19. Andina D, Noguera-Morel L, Bascuas-Arribas M, et al. Chilblains in children in the setting of COVID-19 pandemic. Pediatr Dermatol 2020; 37: 406-11.

20. Fernandez-Nieto D, Jimenez-Cauhe J, Suarez-Valle A, et al. Characterization of acute acral skin lesions in nonhospitalized patients: a case series of 132 patients during the COVID-19 outbreak. J Am Acad Dermatol 2020; 83: e61-3.

21. Landa N, Mendieta-Eckert M, Fonda-Pascual P, et al. Chilblain-like lesions on feet and hands during the COVID-19 Pandemic. Int J Dermatol 2020; 59: 739-43.

22. Kolivras A, Dehavay F, Delplace D, et al. Coronavirus (COVID-19) infection-induced chilblains: a case report with histopathologic findings. JAAD Case Rep 2020; 6: 489-92.

23. Zhou ZR, Ren L, Zhang L, et al. Overly exuberant innate immune response to SARS-CoV-2 infection. SSRN Electronic J 2020. DOI: 10.2139/ssrn.3551623.

24. Torrelo A, Andina D, Santonja C, et al. Erythema multiformelike lesions in children and COVID-19. Pediatr Dermatol 2020; 37: 442-6.

25. Garcia-Gil MF, Garcia Garcia M, Monte Serrano J, et al. Acral purpuric lesions (erythema multiforme type) associated with thrombotic vasculopathy in a child during the COVID-19 pandemic. J Eur Acad Dermatol Venereol 2020 doi: 10.1111/ jdv.16644.

26. Bursal Duramaz B, Yozgat CY, Yozgat Y, et al. Appearance of skin rash in pediatric patients with COVID-19: three case presentations. Dermatol Ther 2020 May 15: e13594.

27. Wang D, Ju XL, Xie F, et al. Clinical analysis of 31 cases of 2019 novel coronavirus infection in children from six provinces (autonomous region) of northern China. Zhonghua Er Ke Za Zhi 2020; 58: 269-74.

28. Morand A, Fabre A, Minodier P, et al. COVID-19 virus and children: what do we know? Arch Pediatr 2020; 27: 117-8.

29. Morey-Olivé M, Espiau M, Mercadal-Hally M, et al. Cutaneous manifestations in the current pandemic of coronavirus infection disease (COVID 2019). An Pediatr 2020; 92: 374-5.

30. Verdoni L, Mazza A, Gervasoni A, et al. An outbreak of severe Kawasaki-like disease at the Italian epicentre of the SARSCoV-2 epidemic: an observational cohort study. Lancet 2020; 395: 1771-8.

31. Labe P, Ly A, Sin C, et al. Erythema multiforme and Kawasaki disease associated with COVID-19 infection in children. J Eur Acad Dermatol Venereol 2020 doi: 10.1111/jdv.16666.

32. Yozgat CY, Uzuner S, Bursal Duramaz B, et al. Dermatological manifestation of pediatrics multisystem inflammatory syndrome associated with COVID-19 in a 3-year-old girl. Dermatol Ther 2020: e13770.

33. Bahrami A, Vafapour M, Moazzami B, et al. Hyperinflammatory shock related to COVID-19 in a patient presenting with multisystem inflammatory syndrome in children: first case from Iran. J Paediatr Child Health 2020; 10.1111/jpc.15048.

34. Pouletty M, Borocco C, Ouldali N, et al. Paediatric multisystem inflammatory syndrome temporally associated with SARS-CoV-2 mimicking Kawasaki disease (Kawa-COVID-19): a multicentre cohort. Ann Rheum Dis 2020; 79: 999-1006. 
35. Deza Leon MP, Redzepi A, McGrath E, et al. COVID-19-associated pediatric multisystem inflammatory syndrome. J Pediatric Infect Dis Soc 2020; 9: 407-8.

36. Ramcharan T, Nolan O, Lai CY, et al. Paediatric Inflammatory Multisystem Syndrome: Temporally Associated with SARS CoV-2 (PIMS-TS): cardiac features, management and shortterm outcomes at a UK Tertiary Paediatric Hospital. Pediatr Cardiol 2020. DOI: 10.1007/s00246-020-02391-2.

37. World Health Organization. WHO Scientific brief: Multisystem inflammatory syndrome in children and adolescents with COVID-19 2020 2020. Available from: https://www. who.int/publications-detail/multisystem-inflammatorysyndrome-in-children-and-adolescents-with-covid-19

38. Toubiana J, Poirault C, Corsia A, et al. Kawasaki-like multisystem inflammatory syndrome in children during the covid-19 pandemic in Paris, France: prospective observational study. BMJ 2020; 369: m2094.

39. Viner RM, Whittaker E. Kawasaki-like disease: emerging complication during the COVID-19 pandemic. Lancet 2020; 395: 1741-3.

40. Nakamura A, Ikeda K, Hamaoka K. Aetiological significance of infectious stimuli in Kawasaki disease. Front Pediatr 2019; 7: 244

41. Rowley AH, Baker SC, Orenstein JM, et al. Searching for the cause of Kawasaki disease: cytoplasmic inclusion bodies provide new insight. Nat Rev Microbiol 2008; 6: 394-401.

42. Kimberlin DW, Brady MT, Jackson MA, et al. Kawasaki disease. Red Book 2018: American Academy of Pediatrics 2018; 490-7.

43. Genovese G, Colonna C, Marzano AV. Varicella-like exanthem associated with COVID-19 in an 8-year-old girl: a diagnostic clue? Pediatr Dermatol 2020; 37: 435-6.

44. Kudryavtseva AV, Neskorodova KA, Staubach P. Urticaria in children and adolescents: an updated review of the pathogenesis and management. Pediatr Allergy Immunol 2019; 30: $17-24$.

45. Caproni M, Giomi B, Volpi W, et al. Chronic idiopathic urticaria: infiltrating cells and related cytokines in autologous serum-induced wheals. Clin Immunol 2005; 114: 284-92.

46. Lee SJ, Ha EK, Jee HM, et al. Prevalence and risk factors of urticaria with a focus on chronic urticaria in children. Allergy Asthma Immunol Res 2017; 9: 212-9.

47. Imbalzano E, Casciaro M, Quartuccio S, et al. Association between urticaria and virus infections: a systematic review. Allergy Asthma Proc 2016; 37: 18-22.

48. Bilbao A, Garcia JM, Pocheville I, et al. Round table: urticaria in relation to infections. Allergol Immunopathol 1999; 27: 73-85. 